\title{
Building Change Detection from Multitemporal Airborne Lidar Data Based on Morphology and Histogram
}

\section{Introduction}

Nowadays, Airborne Laser Scanning (ALS) technology is getting more and more new fields of application. It is caused mainly with fact of the data acquisition for large areas concerning in relatively fast way. The significant independence from lighting and atmospheric conditions also makes it is becoming more widely used for different kinds of examinations.

The above-mentioned features have caused widespread in recent years, use of the ALS technology to create a digital terrain models (DTM) and digital surface model (DSM). In Poland, data acquired during the project ISOK (Information System for Country Protection) covering almost the entire area of the country. Data obtained during the project will be used, inter alia, for the development of flood hazard maps and flood risk maps. The analysis of this problem is presented in [10]. Lidar data in our country are also used for other studies - including in forestry to examining the tree stand [23] and in the methodology of studies related to the fortifications [25]. Due to the relatively short time that has passed since the appearance of the measurement technology, before the implementation of the project ISOK, it was carried out experimental raids on a much smaller scale. They were to test the usefulness and reliability of the airborne laser scanning as a method of obtaining data on the land surface.

Using data obtained at different times for the same area, it is possible to detect places where changes have occurred within the building. In this paper, attempts have been made to automate this process using morphological operators. In addition to assist in the interpretation of the achieved results, it used histograms of differencing image based on elevation data.

* AGH University of Science and Technology, Faculty of Mining Surveying and Environmental Engineering, Department of Geoinformation, Photogrammetry and Remote Sensing of Environmental, Krakow, Poland 
After getting acquainted, based on a literature review, the methods used to detect building changes proposed an original concept, which is described in Chapter 3. The research work was then carried out to test the proposed method for different types of buildings. The course of the tests and the evaluation of the accuracy results are presented in Chapter 4.

\section{The Methods Used to Detect Changes Based on ALS}

One of the directions of airborne laser scanning application is the detection of changes in the area, mainly within the building. Such studies are generally carried out almost exclusively using ALS data for several periods. There are also methods using photogrammetric data as reference (data documenting the state of building in one period) or, as an adjunct to interpret the process based on the results of ALS [11]. The most common methods dedicated to detecting differences in the building are based on the digital surface model (DSM). One of the first such solutions is proposed in [15]. The process is based on the analysis of the image resulting from the difference of the two periods DSM. A slightly different approach is taken in [22]. Search the changes are based on the interpretation of the histogram of the differential image. On the basis of the estimated threshold values indicating the newly created and demolished (destroyed) buildings. The more compound approach is presented in [4]. Beyond the determination of the changes, the authors want to define their character. This is done on the basis of segmentation point clouds into objects, which are then classified in the appropriate class (ground, vegetation, and buildings). Then, based on the raster generated by the codes the nature of change has been specified.

Another solution proposed in [21] is based on a standardized digital surface model (nDSM), free from the influence of topography. Detection of changes in this method consists in performing segmentation based on region growing algorithm (described inter alia in [14]). Creating objects is based on the defined parameters (such as the difference in elevation, typical roof slope) to examine the surrounding of each point (depending on the specific number of neighbors). After the classification step elimination of all objects other than buildings is performed. Thus prepared two sets of data are the basis for the detection of changes in the building. This step is intended to detect and determine the type of change, by comparing the DMSs based on the set parameters of compatibility between data sets given as a percentage.

An interesting solution from the viewpoint of use of the photogrammetric data in the analysis of changes is proposed in [16]. This method is based on the DTM and DSM, which have been based on ALS data, databases on buildings and the normalized differential vegetation index (NDVI). Stage classification aimed at detection of buildings using the standardized digital terrain model (nDTM) with mask OAT (Object Above Terrain) showing land cover objects. The combination of NDVI and OAT 
allows for easy identification of vegetation and anthropogenic objects, which on the basis of a specific size and shape criteria are selected buildings, which form the base of the current buildings. A comparison of the two bases (existing and newly created) allows for map changes in the building, which is subjected to correction based on morphological filters to remove the artifacts.

With the passing of time and the development of computer science more advanced solutions are offered. Worth mentioning is a method based on FLDM (First-Last-Difference Model) presented in [18]. It is based on the use of registration of multiple reflections in the pre-separation vegetation (in order to eliminate these areas from further analysis). A selection of built-up areas is based on the segmentation of the areas obtained by the difference of the model assigns a minimum value of elevation to all high objects in the region and the differential map of DSM. The classification of segments, as buildings and non-buildings is done by using the classification tree.

Another noteworthy method is an algorithm using SSM (Surface Separation 3D Map) presented in [24]. This method is based on determining the distance between the corresponding points in the two periods - if it is over 1 meter it is classified as a divergence. The method can detect small differences ( 0.10 meter), as the changes (which is why it is so important to use the most accurate data). Points, as the segments are classified into three groups: unknown, altered and unaltered. Then the areas that have changed are subjected to further classification aiming to determine its character.

The most complex method is algorithm based on the theory of Dempster-Shafer proposed in [6]. Use it described relationships of points in space (unknown, empty or occupied) specified in the form of the occupancy grid [13]. The next step is modeled as described reality based on the basic belief assignment, which allows us to determine the probability of a given phenomenon (as a range of values). The data is then subjected to segmentation and classification (ground, buildings and vegetation).

On the use of Dempster-Shafer theory is also based the method set out in [17]. It uses the DTM, DSM, NDVI image and the data base of building. It assumes three main stages: detection of buildings, elimination of vegetation areas and detect changes. The detection of changes is leaning for checking the plausibility of assigning the pixel to the buildings class on two layers: resulting from the detection of building (using Dempster-Shafer theory) and comprising between buildings database. Based on this process pixels receive labels informing about the membership in the building class (or not). Identification of changes carried out by checking the correspondence between the individual labels for both sets of data.

\section{The Concept of the Method of Building Change Detection}

After analyzing employed to date solutions it is proposed method, which uses morphological operators and analysis of the histogram. The reason for using such a strategy was a need to determine not only the locations of changes, but also the possibility of interpretation based on elevation ALS data. Identification of areas where 
changes were made for the building largely based on an algorithm presented in [12]. It is based on the DTM and DSM under which, using morphological filters analysis is performed. The general course of conduct during this process shows Figure 1.

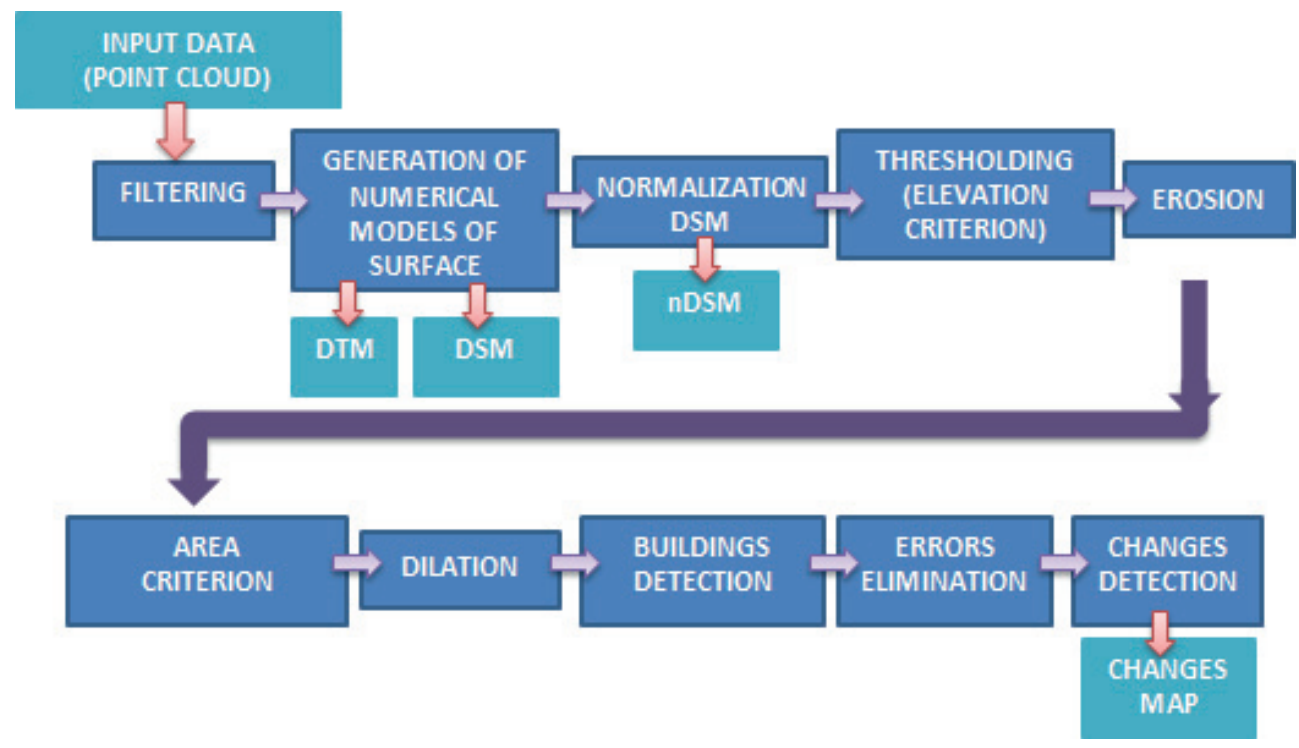

Fig. 1. The steps of change detection

The first step necessary to obtain the correct final results is to perform data filtering. It conduct is necessary due to the elimination of errors that occurred data recording during the raid. This will, on the basis of the classification process based Axellson's algorithm [1], to acquire the ground surface representation. Further treatments within the filter are designed to classify points to the classes of land cover vegetation and buildings. Thus prepared the data will be used to generate DTM and DSM. They will be used in the DSM standardization process (nDSM), which will allow for elimination of the influence of topography, and as a result gain points representing objects located on the terrain surface [21]. To the purpose of the preliminary detection of buildings an elevation criterion was used. It assumes that all objects lying above a certain elevation are buildings. In order to eliminate errors resulting from such assumptions used erosion operator. The process consists in cutting the edges of the homogeneous shape. It is often regarded as a minimum filter [20].

Further elimination of the error is based on area criterion (the appropriate number of contiguous pixels). In relation to the possibility of loss, in previous stages, certain essential information a dilation operator was used for its reconstructing. Action is intended to close the small holes and increases the volume of the figure. It can also be regarded as the maximum filter (reverses the effects of erosion) [20]. Mechanisms of action of these mathematical morphological operations are described, inter alia in [5]. 
Besides erroneously assigned to the building of pixels representing in fact other land cover classes, there was also a need to remove artifacts (usually the edge of the building, which did not change). After this correction data obtained, which presented the state of the building for a period of time. Changes in the buildings are obtained by subtractiing such maps.

Based on maps obtained in this way and elevation data from different periods of time, it made the second stage of the analysis being aimed at determining the precise nature of happening changes based on the interpretations of information included in the differential map histogram. Figure 2 shows a simplified diagram of proceedings at this stage.

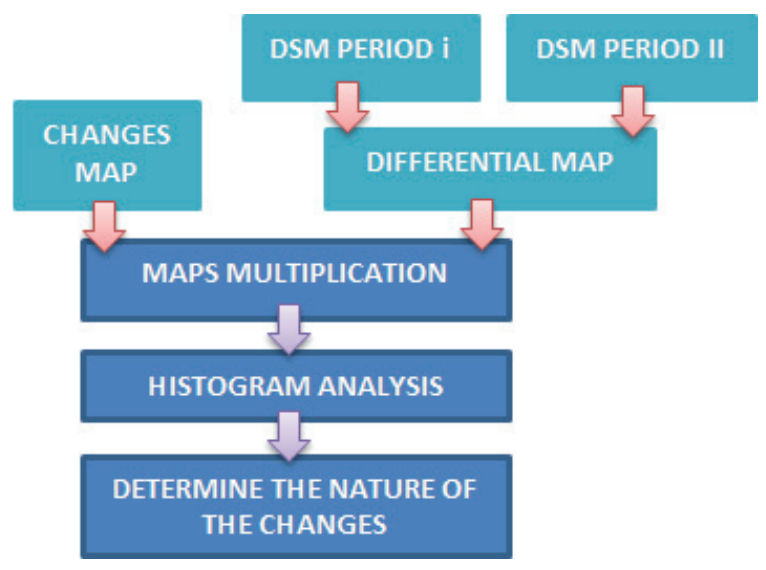

Fig. 2. The steps in determining the type of changes

Using elevation data recorded at different times are generated in the form of a grid raster map. Through substracting the resulting maps differential map presenting discrepancies in the given period are received. With using the get earlier map of the location of changes, these data served for further analysis. The resulting image was used for further analysis involving an attempts of interpretation of the type of changes based on information presented on the histogram [22].

\section{Research}

\subsection{Test Data}

Analyses to detect changes within the building was made based on the data recorded in two raids ALS for the area of the city of Cracow for the years: 2006 and 2012. Details of the characteristics of the obtained data found in $[2,8,9]$. The study was performed in two stages. In the first place are detected locations, which changes were made in the building. Then based on the differential image histogram analysis their character was determined. 
To research the selected seven sites in the city of Cracow differentiated by the type of building and vegetation cover. The following are approximate characteristics:

- area I: modern university campus consisting of several buildings with interesting architecture, with an area of approximately 31 hectares,

- area II: shopping center created in areas of former industrial facilities covering an area of 20 hectares,

- area III: 30-hectare part of the city center being characterized by a high-housing and an intense plant lid,

- area IV: university buildings about the uniform building development occupying the area of 30 hectares,

- area V: area about the single-family and modular building about the area of 32 hectares,

- area VI: service buildings covering an area of 7 hectares,

- area VII: diversified city center building development (in the majority block of flats) filling 40 hectares.

Research began with the appropriate data preparation stage - filtering. In the course of the removed points which have been wrongly registered (low point), and that the classification points to the ground class (Axelsson's algorithm [1]), and then the category: vegetation (based on giving ranges to the relative height) and the buildings (on the basis of the minimum size edge of the roof). Then, DTM and DSM (grid raster, cell size 0.3 meter) are generated based on elevation data. After manual adjustment, they are exported to the Surfer ASCII format. The next step was to import elevation data representing terrain and its coverage to Matlab. In the next stage, it was necessary to load elevation data and the execution of standardization imported DSM based on normal function. Then, on the basis of a standardized digital surface model (nDSM) it made with exploiting the function thresh of classification of points to the class of the building on the basis of their relative height (thresholding). In order to eliminate irregular shaped objects that have met this condition applied erosion (function erode) with its own defined structural element (Fig. 3).

a)

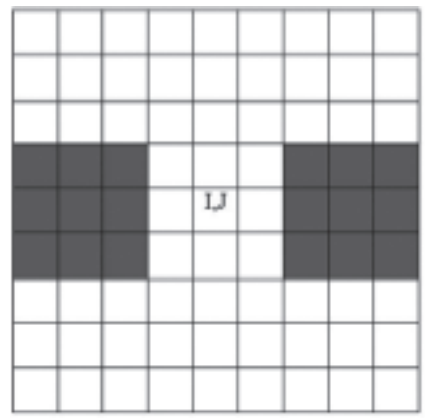

b)

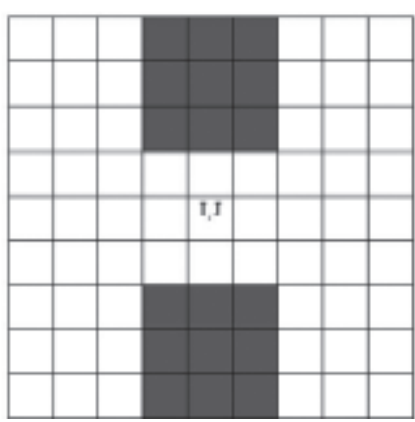

Fig. 3. An example of the applied filter: a) horizontal; b) vertical 
This process examines whether the pixels within $0.5 \mathrm{~m}$ to the left or right of center are set to 1 (analogously top-down for vertical operator). In order to further eliminate the disturbances occurring on the image in the form of e.g. high-density vegetation, applied the area criterion (contacting the appropriate number of pixels - bwareaopen function). Pixels satisfying this condition are given a value of 1 (others 0 ).

Due to the diversity of land cover for each of the areas was necessary to adopt individual relative height (thresholding) and area parameters. Their summary is presented in Table 1.

Table 1. Parameters assumed during the change detection

\begin{tabular}{|c|c|c||}
\hline \multirow{2}{*}{ Area } & \multicolumn{2}{|c|}{ Parameters } \\
\cline { 2 - 3 } & $\begin{array}{c}\text { relative } \\
\text { height [m] }\end{array}$ & $\begin{array}{c}\text { area in pixels } \\
\text { (pixel = 0.30 m) }\end{array}$ \\
\hline \hline I & 4.0 & 3000 \\
\hline II & 3.0 & 4000 \\
\hline III & 3.0 & 3000 \\
\hline IV & 3.0 & 3000 \\
\hline V & 3.0 & 2500 \\
\hline VI & 4.5 & 2500 \\
\hline VII & 4.5 & 3000 \\
\hline
\end{tabular}

At performing previous operations a problem of the loss of information appeared about the shape of buildings (irregular edges, etc.). The recovery of the original shape of the building obtained on the basis of the dilation (function dylat) with identically defined the structural element as in the case of erosion (Fig. 3). Unfortunately, the result of the operation has not eliminated the problem of vegetation classified as buildings. For this purpose, the compactness parameter [12] is used with the following characters:

$$
\text { Compactness }=\frac{\text { Area } \cdot \text { Perimeter }^{2}}{4}
$$

Besides erroneously assigned to the building of pixels representing in fact other land cover classes, there was also a need to remove artifacts (usually the edge of buildings that have not changed). 


\subsection{Accuracy Analysis}

As a result of the script, which was developed in Matlab (without taking into account the stage of elimination of errors) obtained images of buildings in 2006 and 2012 and use changes in the form of three classes: the building torn down $(-1)$, the new building (1), and no change (0).

Table 2. Correctness building detection

\begin{tabular}{|c|c|c|c|c|c|c|c|c|}
\hline \multirow{2}{*}{ Period } & \multirow{2}{*}{ Nature of the pixel } & \multicolumn{7}{|c|}{ Area } \\
\hline & & I & II & III & IV & V & VI & VII \\
\hline \multirow{5}{*}{2006} & $\begin{array}{l}\text { Correctly detected } \\
\text { buildings }\end{array}$ & 71037 & 120074 & 1366937 & 637000 & 417920 & 124104 & 452987 \\
\hline & $\begin{array}{l}\text { Number of pixels } \\
\text { classified as building }\end{array}$ & 72391 & 160439 & 1481480 & 707302 & 469189 & 126799 & 487348 \\
\hline & $\begin{array}{l}\text { Classification } \\
\text { accuracy (producer's } \\
\text { accuracy) [\%] }\end{array}$ & 98.13 & 74.84 & 92.27 & 90.06 & 89.07 & 97.87 & 92.95 \\
\hline & $\begin{array}{l}\text { Number of pixels } \\
\text { representing the } \\
\text { building }\end{array}$ & 79337 & 154780 & 1441835 & 708751 & 712723 & 133384 & 602536 \\
\hline & $\begin{array}{l}\text { Reliability } \\
\text { (user's accuracy) [\%] }\end{array}$ & 89.54 & 77.58 & 94.81 & 89.88 & 58.64 & 93.04 & 75.18 \\
\hline \multirow{5}{*}{2012} & $\begin{array}{l}\text { Correctly detected } \\
\text { buildings }\end{array}$ & 377759 & 909800 & 1403374 & 730420 & 500867 & 207018 & 648648 \\
\hline & $\begin{array}{l}\text { Number of pixels } \\
\text { classified as building }\end{array}$ & 548356 & 1030690 & 1728495 & 818323 & 558021 & 208904 & 777591 \\
\hline & $\begin{array}{l}\text { Classification } \\
\text { accuracy (producer's } \\
\text { accuracy) [\%] }\end{array}$ & 68.89 & 88.27 & 81.19 & 89.26 & 89.76 & 99.10 & 83.42 \\
\hline & $\begin{array}{l}\text { Number of pixels } \\
\text { representing the } \\
\text { building }\end{array}$ & 390822 & 923655 & 1451138 & 787952 & 810038 & 220270 & 785134 \\
\hline & $\begin{array}{l}\text { Reliability } \\
\text { (user's accuracy) [\%] }\end{array}$ & 96.66 & 98.50 & 96.71 & 92.70 & 61.83 & 93.98 & 82.62 \\
\hline
\end{tabular}


On the basis of Table 2 it can be concluded that the accuracy of automatic detection of buildings based on the use of morphological filters gives satisfactory results. The evaluation is based on a slightly modified approach used in the validation study conducted supervised classification of satellite images. It is based on the proportional error matrix based on which parameters are calculated: user's accuracy and producer's accuracy [19]. The first one is characterized by the reliability, i.e. the number of correctly classified pixels compared to the total number of pixels representing the class in reality. The second figure is a measure of the accuracy of classification and is the ratio of correctly classified pixels of the class to the total number of pixels of the class. In most indicators of precision hover around $90 \%$. This can be considered a very good result. Only in isolated cases, the values of these parameters are significantly smaller (at $60 \%$ ). Any inaccuracies have individual character and should be independently analyzed.

The analysis of the obtained maps of location building changes is based on the completeness and correctness [7]. These parameters take values in the interval $[0,1]$ - the higher the value, the better the accuracy of the resulting maps. Attempts have been made to optimize performance by reducing noise edge (executed by the area criterion $=500$ pixels). Results obtained before (a) and after (b) noise reduction for the areas studied are presented in Table 3. Removing artifacts caused in most cases improve the precision indicators. However, in some cases (e.g. for the area III) the parameter values have fallen, which mainly can be caused by too radical filtration associated with diverse land cover (dense vegetation).

Table 3. The obtained accuracy values of map of changes

(a)

\begin{tabular}{|l|c|c|c|c|c|c|c||}
\hline \multicolumn{1}{|c|}{ Parameters/Area } & I & II & III & IV & V & VI & VII \\
\hline Correctness & 0.65 & 0.87 & 0.14 & 0.49 & 0.45 & 0.96 & 0.49 \\
\hline Completness & 0.97 & 0.97 & 0.48 & 0.78 & 0.56 & 0.88 & 0.75 \\
\hline
\end{tabular}

(b)

\begin{tabular}{|l|c|c|c|c|c|c|c||}
\hline \multicolumn{1}{|c|}{ Parameters/Area } & I & II & III & IV & V & VI & VII \\
\hline Correctness & 0.65 & 0.87 & 0.06 & 0.47 & 0.42 & 0.98 & 0.47 \\
\hline Completness & 0.98 & 0.97 & 0.48 & 0.96 & 0.85 & 0.92 & 0.87 \\
\hline
\end{tabular}

\subsection{Removal of Artifacts}

The results obtained on the basis of the functions implemented in Matlab showed some imperfections - there are places on the resulting map where there are no building changes in real terms. This is due to the incorrect classification of certain pixels as buildings (most dense vegetation, which fulfills elevation and area criteria). Another important problem is the errors resulting from the relatively low situational 
accuracy of ALS manifested in the form shown on the map of the resulting pixel, which in fact represent the edges of the buildings that has not changed. A solution to eliminate these artifacts is to use the compactness parameter (model 1). This process was based on the vector data (raster format conversion). It allowed for the removal of objects taking the extreme values of the indicator (buildings assumed values from the interval around the mean value). However, it failed to fully exclude artificial change - particularly for individual trees. Additionally, the situation is complicated by the complexity of the geometry of the buildings, which affects the possibility of elimination of misclassified pixels. Figure 4 shows the effect of the application of the compactness parameter to eliminate errors for the area $\mathrm{V}$.

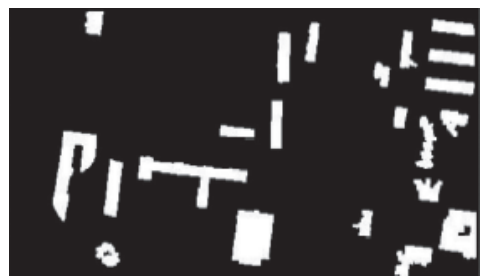

Buildings 2006

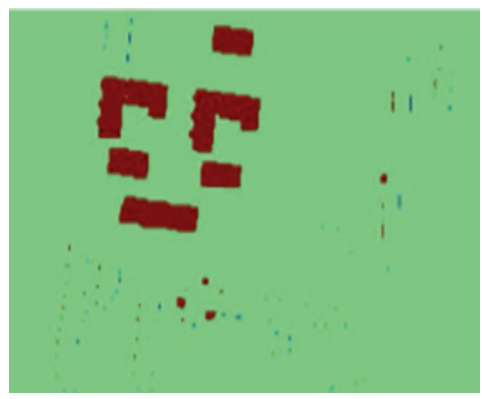

Buildings change

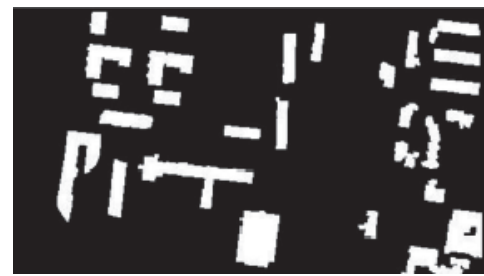

Buildings 2012

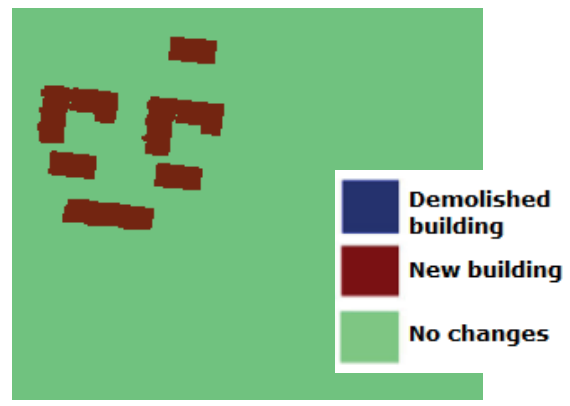

Buildings change

(compactness parameter)

Fig. 4. The elimination of artifacts based on the compactness parameter

\subsection{Analysis of Building Changes}

In order to determine the nature of the changes in localized areas used modified approach proposed in [22]. It is based on obtaining information about the type of change based on a histogram analysis of differential maps showing elevation differences $[\mathrm{m}]$ in the analyzed period of time (current data - outdated data). Based on the resulting map were made an attempts to determine the exact nature of the change. Histograms with maps presenting the height differences for each areas in the test period are shown in Table 4. 
Table 4. Differential map histograms for selected area

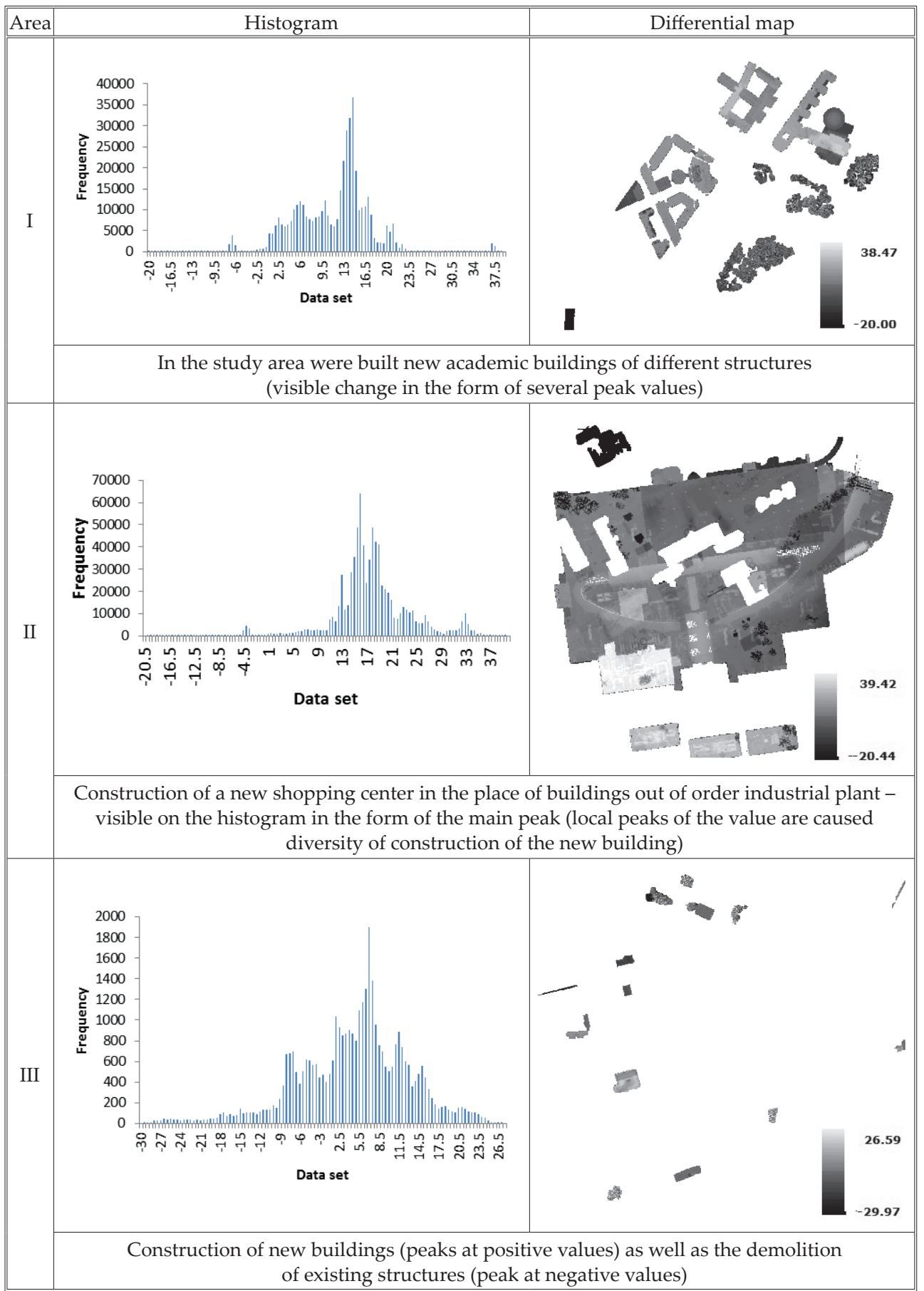


Table 4 cont.

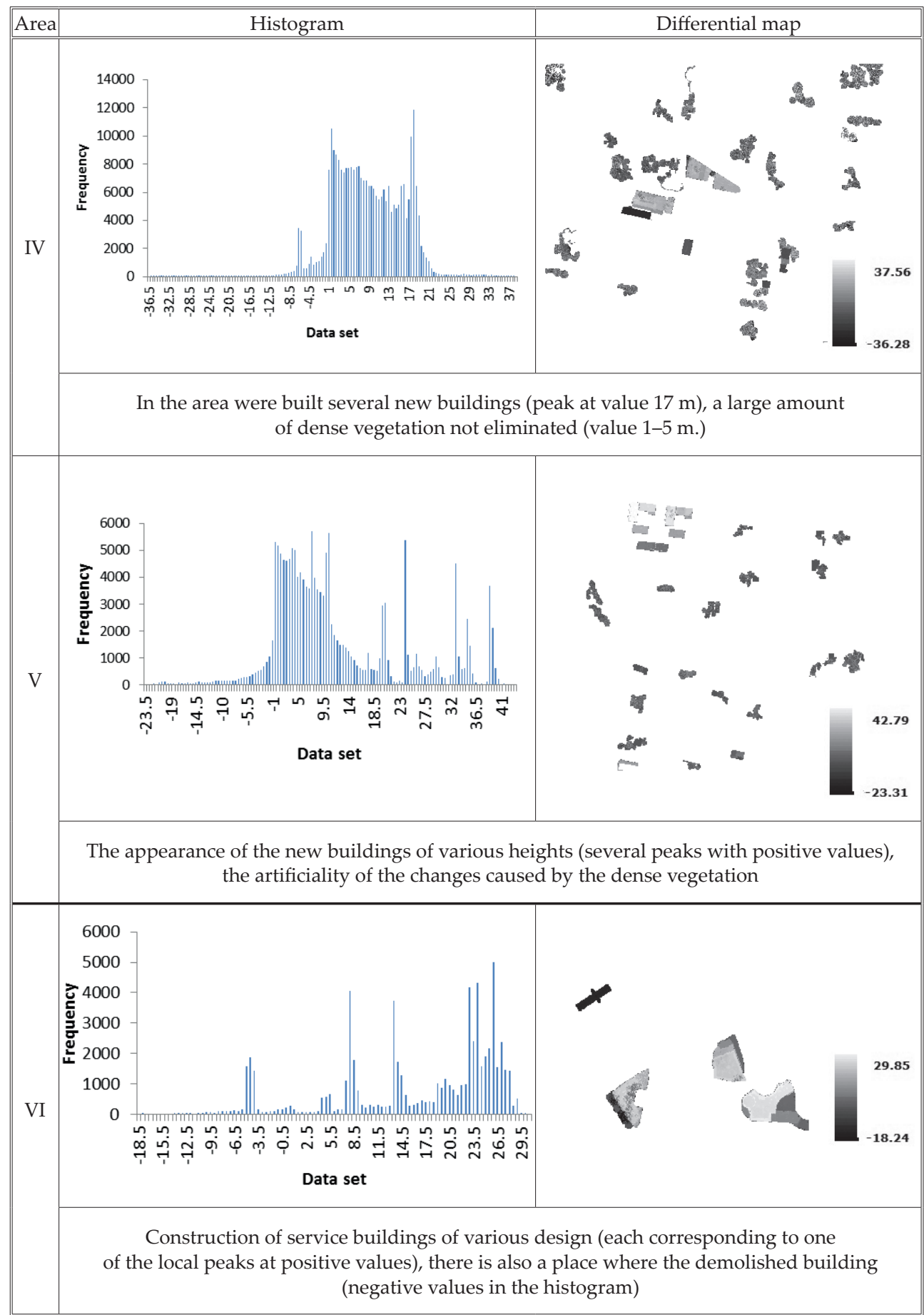




\section{Table 4 cont.}

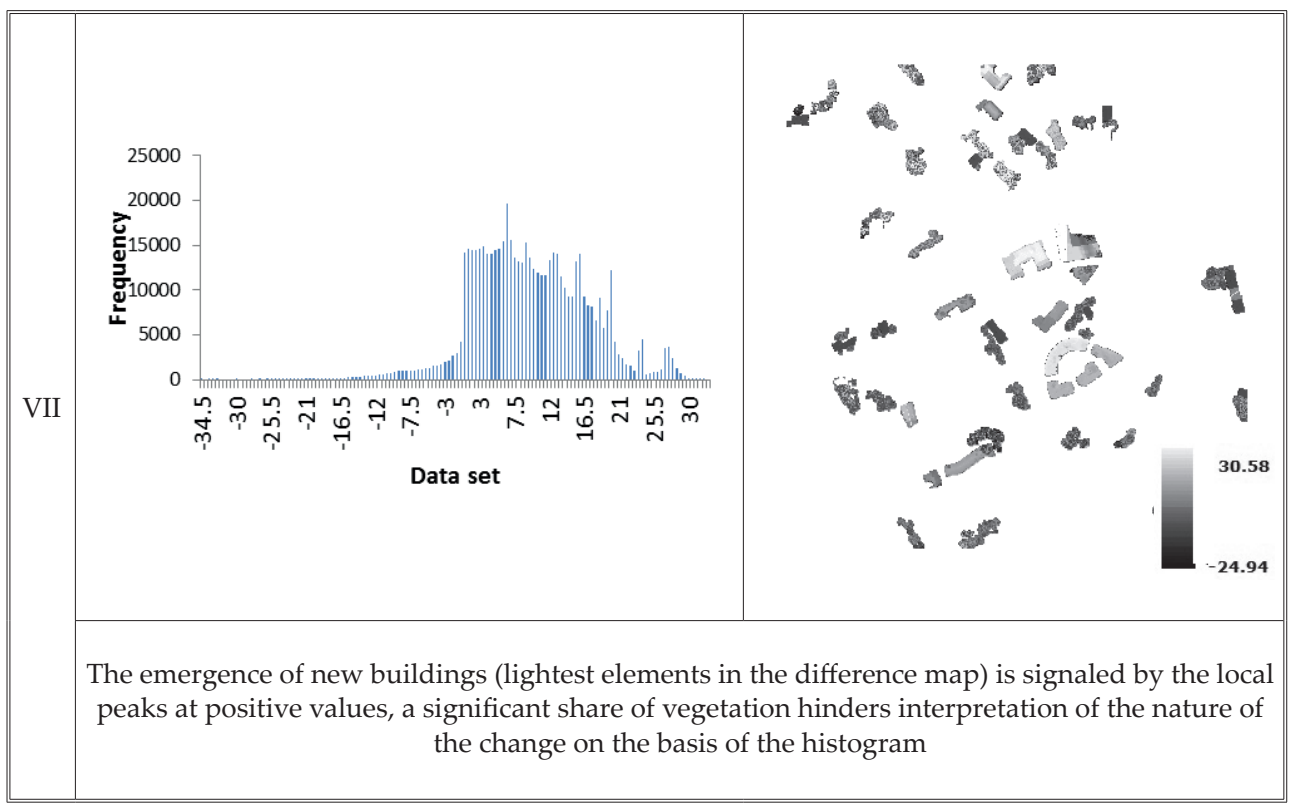

The analysis of the histograms allows us for simple reasoning about character of the change which occured on the green area. Analyzing more amendments collectively causes some difficulties in the unambiguous assignment of the change to a certain place. However, it is quite possible to efficiently obtain information about the kinds of changes - it perfectly visible e.g. histogram for areas V and VI, where the appearance of a new building (change ground $\rightarrow$ building) corresponds to one of the local peak values on the chart. Existing histograms for areas II and VII local maximum in the vicinity of extreme values of the graph indicate the occurrence of a building (a portion thereof) which is characterized by much higher construction than the others. Extreme negative values generally mean the demolition of the building (change building $\rightarrow$ ground (low vegetation)) - an area I and II. Not many locally dominant values (see e.g. chart for the area I) suggest incorrectly classified, as a change in dense vegetation. Unfortunately it was unable to fully eliminate this problem.

Analyzing the histograms of information on the whole areas leads to qualitative information, which does not always allow for precise assignment of the nature of the changes to a specific location. This situation may occur when the study area, a number of new buildings (change of land $\rightarrow$ buildings) of similar height (in the histogram of this change will be seen as one peak - by default interpreted as the appearance of one building). To make a clear analysis, it was necessary to consider the information on each building separately. 


\subsection{Trying to Explain Critical Errors}

The proposed methodology for the building change detection, as shown by the results in Table 3, has not proved to be effective for all the areas in question. The reason for this could be a different type of development in the area, the state of the vegetation cover (its integrity) or the appearance of a new building of the place of the demolished.

a)
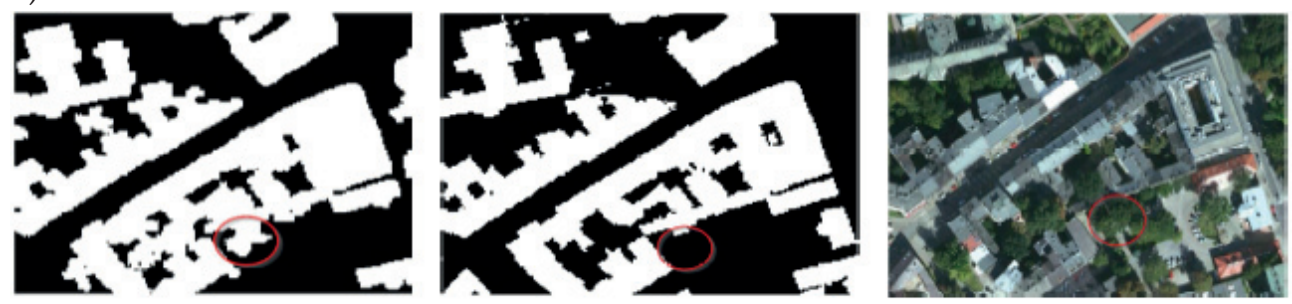

b)
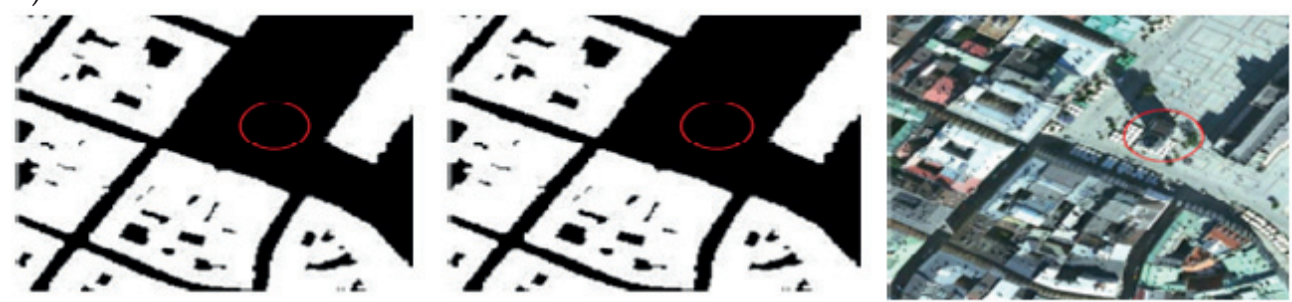

c)
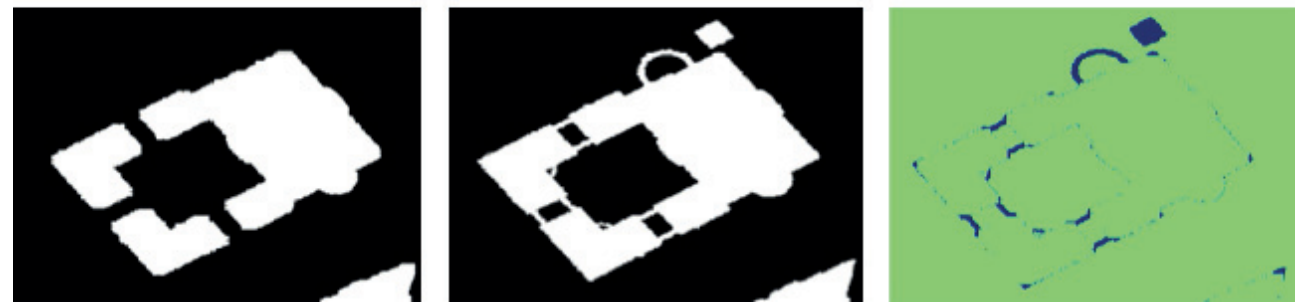

Fig. 5. Examples of errors during the building detection

The process of building detection for each of the periods proved to be satisfactory, although it could not avoid some inaccuracies - classification of vegetation, as the building (Fig. 5a), the classification of the building as a non-building (Fig. 5b), whether the loss of information about the shape of the building by applying filters (Fig. 5c). 


\section{Summary}

Proposed for the building change detection methods allowed the authors to obtain correct results. However, it failed to eliminate some inconsistencies affecting the accuracy of the whole process of analysis. The main factor was the existence of disrupting the studied areas of dense vegetation, which implemented the algorithm incorrectly classified as buildings. This state of affairs is enhanced by the fact that the data used in the analysis were obtained at different periods of vegetation, which may cause an artificial change effect. Attempts to correct this problem based on the compactness parameter ended with partial success - managed to remove only a portion of the objects misclassified. The reason for this is inter alia the fact that the shape of diverse buildings that obstruct the selection of an appropriate range of values, which is characterized by a class of buildings. The process of change detection based on the difference in buildings in a given period (2006-2012) at the outset is affected by the inability to detect changes in reconstruction (without changing the contour of the building) and the emergence of a new building in the place of a pre-existing ones - in such cases there is a loss of information (theoretically no change). This fact is all the more important due to the inability to evaluate the nature and magnitude of changes on the basis of the histogram. On this basis, it can determine the nature of the typical changes. The test area is less than the identification of the type of change is easier.

An important factor in having a large impact on the results is the quality of the data. Apart from certain discrepancies resulting from any failure of similar conditions of registration (different seasons), it should pay attention to the passage of time, which influenced the development of airborne laser scanning technology. It causes the data for the current period (2012) is obtained with a higher density of scan or has additional parameters (e.g. the number of reflections, etc.). The analysis presented in the form of grid raster map with a 0.30 -meter cell size. The single value adopted for all areas makes local discrepancies from the assumed values of density scan (12 points per square meter) are not taken into account, and thus, in conjunction the lack of adequate amounts of information therecan be some misrepresentation with regard to the presentation of the land surface in a given place. The solution to this problem may be applicable in the form of adaptive grid, which the grid size cell is dependent on the local density scan. In this way in the given place it could obtain the maximum possible accuracy. Raster does not cause such averaging a size cell, especially for areas with a smaller number of dots per unit area. This issue is addressed, inter alia, in [1]. The presented method, using morphological filters, height and area criteria can be successfully used to detect changes in buildings. The results are at a good level (shown is the value derived indicators, especially correctness, which for most areas are at a level of at least 0.80 [3]). An additional advantage of the presented solution is the simplicity and the fact that operator intervention is required only at the beginning and during the selection of the parameters - the remaining steps are fully automated. Enrichment thus obtained information based on the elevation data possible to determine on the basis of a histogram type of change. 


\section{References}

[1] Axelsson P.: DEM Generation from Laser Scanner Data Using AdaptiveTIN Models. The International Archives of Photogrammetry and Remote Sensing, vol. 33, 2000, pp. 110-117.

[2] Borowiecki I., Ślusarski M.: Lotniczy skaning laserowy LIDAR miasta Krakowa (ocena dokładnościowa). Infrastruktura i Ekologia Terenów Wiejskich, nr 3, 2010, pp. 127-137.

[3] Champion N.: Detection of Unregistered Buildings for Updating 2D Databases. EuroSDR, Amsterdam 2009.

[4] Choi K., Lee I., Kim S.: A feature based approach to automatic change detection from LIDAR data in urban areas. The International Archives of Photogrammetry and Remote Sensing, vol. 38, part 3/W8, 2009, pp. 259-264.

[5] Haralick R.M., Sternberg S.R., Zhuang X.: Image Analysis Using Mathematical Morphology. IEEE Transactions on Pattern Analysis and Machine Intelligence, vol. PAMI-9, no. 4, 1987, pp. 532-550.

[6] Hebel M., Arens M., Stilla U.: Change detection in urban areas by object based analysis and on-the fly comparision of multi-view ALS data. ISPRS Journal of Photogrammetry \& Remote Sensing, vol. 86, 2013, pp. 52-64.

[7] Hepike C., Mayer H., Wiedermann C., Jamet O.: Automated reconstruction of topographic objects from aerial images using vectorized map information. Archives of Photogrammetry and Remote Sensing, vol. 32, 1997, pp. 47-56.

[8] Jędrychowski I.: Lotnicze skanowanie laserowe Krakowa. Archiwum Fotogrametrii, Kartografii i Teledetekcji, vol. 17a, 2007, pp. 339-345.

[9] Kurczyński Z., Stojek E., Cisło-Lesicka U.: Zadania GUGiK realizowane w ramach projektu ISOK. [in:] Podręcznik dla uczestników szkoleń z wykorzystywania produktów LIDAR, Warszawa 2014, pp. 22-56.

[10] Kurczyński Z.: Mapy zagrożenia powodziowego i mapy ryzyka powodziowego a dyrektywa powodziowa. Archiwum Fotogrametrii, Kartografii i Teledetekcji, vol. 23, 2012, pp. 209-217.

[11] Matikainen L., Hyyppä J., Ahokas E., Markelin L., Kaartinen H.: Automatic detection of buildings and changes in building for updating of maps. Remote Sensing, vol. 2(5), 2010, pp. 1217-1248.

[12] Meng X., Wang L., Currit N.: Morphology-based Building Detection from Airborne Lidar Data. ASCM-ASPRS 2002 Annual Conference Proceedings, Photogrammetric Engineering and Remote Sensing 2009, vol. 75, no. 4, pp. 437-442.

[13] Moravec H., Elfes A.: High resolution maps from wide angle sonar. [in:] 1985 IEEE International Conference on Robotics and Automation, IEEE Computer Society Press, 1985, pp. 116-121. 
[14] Morgan M., Habib A.: Interpolation of lidar data and automatic building extraction. [in:] XXII FIG International Congress: ACSM/ASPRS Annual Conference: proceedings, American Society for Photogrammetry and Remote Sensing, Washington 2002 [CD].

[15] Murakami H., Nakagawa K., Hasegawa H., Shibata T., Iwanami E.: Change detection of buildings using an airborne laser scanner. ISPRS Journal of Photogrammetry \& Remote Sensing, vol. 54, 1999, pp. 148-152.

[16] Olsen B., Knudsen T.: Automated change detection for validation and update of geodata. 6a Semana Geomática, Barcelona, 8-11 Febrero 2005.

[17] Rottensteiner F.: Automated updating of building data bases from digital surface models and multi-spectral images: potential and limitations. International Archives of Photogrammetry, Remote Sensing and Spatial, vol. 37, part B3a, 2008, pp. 265-270.

[18] Rutzinger M., Rüf B., Höfle B., Vetter M.: Change detection of buildings from airborne laser scanning acquired in short time intervals. The International Archives of Photogrammetry and Remote Sensing, vol. 38, part 7B, 2010, pp. 475-480.

[19] Story M., Congalton R.G.: Accuracy assessment: A user's perspective. Photogramemetric Engineering and Remote Sensing, vol. 52, 1986, pp. 397-399.

[20] Tadeusiewicz R., Korohoda P.: Komputerowa analiza i przetwarzanie obrazów. Wydawnictwo Fundacji Postępu Telekomunikacji, Kraków 1997.

[21] Vögtle T., Steine E.: Detection and recognition of changes in building geometry derived from multitemporal laser scanning data. The International Archives of Photogrammetry, Remote Sensing and Spatial Information Sciences, vol. 35, part B2, 2004, pp. 428-433.

[22] Vu T.T., Matsuoka M., Yamazaki F.: LIDAR-based change detection of building in dense urban areas. [in:] Geoscience and Remote Sensing Symposium, 2004. IGARSS '04. Proceedings. 2004 IEEE International (Volume 5), IEEE, 2004, pp. 3413-3416.

[23] Wężyk P., Solecki K.: Określanie wysokości drzewostanu nadleśnictwa Chojna w oparciu o lotniczy skaning laserowy (ALS). Archiwum Fotogrametrii, Kartografii i Teledetekcji, vol. 18B, 2008, pp. 663-672.

[24] Xu S., Vosselman G., Oude Elberink S.: Detection and classification of changes in buildings from airborne laser scanning data. ISPRS Annals of the Photogrammetry, Remote Sensing and Spatial Information Sciences, vol. II-5/W2, 2013, pp. 343-348.

[25] Zawieska D., Ostrowski W., Antoszewski M.: Wykorzystanie danych lotniczego skaningu laserowego w metodyce badawczej zespołów fortyfikacji nowszej w Polsce. Archiwum Fotogrametrii, Kartografii i Teledetekcji, vol. 25, 2013, pp. 303-314. 